\title{
Estimation of Cranial Capacity in 17-26 Years Old University Students
}

\author{
Estimación de la Capacidad Craneana en Estudiantes Universitarios entre 17 y 26 Años de Edad \\ "Niyazi Acer; "**Mustafa Usanmaz; "Umut Tugay \& ***Tolga Erteki $n$
}

ACER, N., USANMAZ, M.; TUGAY, U. \& ERTEKI'N, T. Estimation of cranial capacity in 17-26 years old university students. Int. J. Morphol., 25(1):65-70, 2007.

SUMMARY: It is natural that there is close relationship between cranial capacity, and the size of brain. Several studies have estimated the cranial capacity which indirectly reflects the brain volume. This study was carried out on 366 (226 male and 140 female) healthy university students aged between 17-26 years old at Mugla University, Mugla, Turkey. By using linear dimensions of the head the mean cranial capacity and SD in males and females were $1411.64 \pm 118.9 \mathrm{~cm}^{3}$ and $1306.95 \pm 162.9 \mathrm{~cm}^{3}$, respectively. There was a significant difference between genders $(\mathrm{p}<0.05)$. This investigation was showed the cranial capacity is larger in males than females. We also proposed a regression formula that could be used to predict the cranial capacity.

KEY WORDS: Craniometry; Cranial capacity; Regresion formula.

\section{INTRODUCTION}

A number of accurate methods for determining the cranial capacity (CC) of the macerated skulls are available (Haack \& Meihoff, 1971; Hwang et al., 1995; Manjunath, 2002a,b; Golalipour et al., 2005; ). Some of the investigators have estimated the $\mathrm{CC}$ in the past which indirectly reflects the brain volume (Gault et al., 1988; Wolf et al., 2003; Mazonakis et al., 2004). One of the most satisfactory method for measuring CC of a dry skull is measuring the amount of water poured into a balloon which introduced into the cranial cavity through the foramen magnum (Manjunath, 2002a; Acer et al., 2006). Most of those available studies have been made on dry skulls using linear dimensions, packing methods or occasionally radiological methods. It is also an indirect approach to evaluate the size of the brain (Mac Kinnon, 1995; Dekaban, 1977; Manjunath, 2002a; Mazonakis et al.).

$\mathrm{CC}$, which is in close correlation with brain volume, reflects racial characteristics and thus has been though to be one of the commonest items in physical anthropological studies (Hwang et al.; Manjunath, 2002b; ). A few studies have been made on living subjects (Golalipour et al.). This information is useful in correlating cranial capacity with other cranial measurements and in studies of primate phylogeny.
Medically, an analysis of cranial capacity exposes another aspect of growth and development and permits critical evaluation of unusually large, small or misshapen (Haack \& Meihoff).

An attempt has been made in the present study to estimate the cranial capacity of living subjects using the linear dimensions of the heads in 17-26 years old healthy university students. The purpose of the study was to investigate the relation between the $\mathrm{CC}$ and age, body weight, body height, body mass index (BMI) in living subject.

\section{MATERIAL AND METHOD}

This study was carried out on 366 healthy 17-26 years old (226 males, 140 females) Mugla University students, at the Mugla University, Mugla, Turkey, between January and March 2006. Body height $(\mathrm{cm})$ and body weight $(\mathrm{kg})$ of the students were measured and BMI $\left(\mathrm{kg} / \mathrm{m}^{2}\right)$ was calculated. BMI was calculated by dividing the weight in kilograms by the square of height in meters. BMI groups were defined using

\footnotetext{
* Assist. Prof. Dr., Mugla University, School of Health Sciences, Mugla, Turkey.

** MD Mugla State Hospital, Neurosurgery Clinic, Mugla, Turkey.

*** PhD Student., Erciyes University, Medical Faculty, Anatomy Department, Kayseri, Turkey.
} 
the World Health Organization's (WHO) classification system (Report of a WHO consultation, 2000). At each examination, measurements of height and weight were obtained by trained examiner according to a standardized protocol. Height was measured to the nearest $0.1 \mathrm{~cm}$ with an Iowa Height Board, and weight to the nearest $0.1 \mathrm{~kg}$ using a balance beam metric scale. Since soft tissue, especially the subcutaneal fat tissue's thickness might effect the measurements we used only the cases with normal BMI values. Descriptive data was given as mean and standard deviation.

In each case the following linear dimensions of the head were measured by craniometry:

- Maximum head length (Glabella-inion length: L).

- Maximum head breadth (measured between parietal eminences: W)

- Auricular height (external acoustic meatus to the highest point of the vertex: $H$ ) using an auricular head spanner.

Each measurement was taken to the nearest millimeter at least three times and the average was considered for computation. The $\mathrm{CC}$ was calculated using the following formula given by Williams et al. (1995) and Manjunath (2002b).

Males : $0.000337(\mathrm{~L}-11)(\mathrm{W}-11)(\mathrm{H}-11)+406.01$

Females: 0.000400(L-11) (W-11) (H-11) +206.60
The data for each person was recorded in a special form and then analyzed by SPSS 11.0. For comparison of the means of anthropometric measurements Student $t$ test $(p>0.05)$ was used for sexes.

The interaction between the linear measurements and the BMI were analyzed using Pearson correlation test and a regression formula was proposed for the prediction of CC using the age, body weight, body height and BMI value. A paired Student's $t$-test was applied in order to investigate possible statistical differences among formulaes. $\mathrm{CC}$ was calculated for both sexes. Thus actually proved to be easy using these formulae for calculate CC.

\section{RESULTS}

Means $( \pm \mathrm{SD})$ of head length, head width and auricular height in both sexes are depicted in Table I. The means $\left( \pm \mathrm{SD}\right.$ ) of cranial capacity were $1411.64 \pm 118.9 \mathrm{~cm}^{3}$ (Range: 1137.33-1798.92), and of females: $1306.95 \pm 162.97 \mathrm{~cm}^{3}$ (Range: 991.59-1930.5) in males, respectively. Male CC was larger than female $(\mathrm{p}<0.05)$. A positive correlation was found between CC and age, body weight, body height and BMI. Different formulae and r, F, p values were proposed (Table II).

Table I. Showing various parameters on 366 healthy 17-26 years old both sexes, Mugla University students, Turkey.

\begin{tabular}{|c|c|c|c|c|c|}
\hline & $\mathrm{N}$ & Minimum & Maximum & Mean & Std. Deviation \\
\hline Age & 366 & 17 & 26 & 19.83 & 1.96 \\
\hline Body Weight (kg) & 366 & 47 & 90 & 65.34 & 8.88 \\
\hline Body Height $(\mathrm{cm})$ & 366 & 155 & 193 & 174.21 & 8.18 \\
\hline BMI $\left(\mathrm{kg} / \mathrm{m}^{2}\right)$ & 366 & 18.42 & 24.82 & 21.43 & 1.61 \\
\hline Head length (mm) & 366 & 152 & 205 & 182.79 & 8.02 \\
\hline Head width (mm) & 366 & 136 & 170 & 154.62 & 6.50 \\
\hline Auricular height (mm) & 366 & 107 & 168 & 127.94 & 9.74 \\
\hline WxHxL (cm) & 366 & 2533.35 & 5275.2 & 3626.39 & 451.87 \\
\hline Cranial capacity $\left(\mathrm{cm}^{3}\right)$ & 366 & 991.59 & 1939.50 & 1371.60 & 146.37 \\
\hline
\end{tabular}

Table II. Linear curve estimation between cranial capacity (CC ) and age, weight, height, body mass index (BMI), on 366 healthy 17-26 years old both sexes, Mugla University students, Turkey.

\begin{tabular}{|c|c|c|c|c|c|c|c|c|c|c|c|c|}
\hline \multirow[b]{2}{*}{ Parameters } & \multicolumn{4}{|c|}{ Men } & \multicolumn{4}{|c|}{ Women } & \multicolumn{4}{|c|}{ Both sex } \\
\hline & $\mathbf{n}$ & $\mathbf{r}$ & $\mathbf{F}$ & $\mathbf{p}$ & $\mathbf{n}$ & $\mathbf{r}$ & $\mathbf{F}$ & $\mathbf{p}$ & $\mathbf{n}$ & $\mathrm{r}$ & $\mathrm{F}$ & $\mathrm{p}$ \\
\hline Age-CC & 226 & 0.127 & 32.69 & $<0.000$ & 140 & 0.151 & 24.50 & 0.000 & 366 & 0.160 & 69.14 & $<0.000$ \\
\hline Body Weight-CC & 226 & 0.129 & 33.11 & $<0.000$ & 140 & 0.351 & 74.79 & 0.000 & 366 & 0.305 & 160.1 & $<0.000$ \\
\hline Body Height-CC & 226 & 0.074 & 17.96 & $<0.000$ & 140 & 0.391 & 88.55 & 0.000 & 366 & 0.293 & 150.6 & $<0.000$ \\
\hline WxHxL-CC & 226 & 1.000 & 26619 & $<0.000$ & 140 & 1.000 & 23727 & 0.000 & 366 & 0.990 & 3774 & $<0.000$ \\
\hline BMI-CC & 226 & 0.062 & 14.82 & $<0.000$ & 140 & 0.050 & 7.25 & 0.000 & 366 & 0.111 & 45.48 & $<0.000$ \\
\hline
\end{tabular}


Table III. Different formulae (F1:age, F2:weight, F3:height, F4:BMI and F5: WxHxL).

\begin{tabular}{|c|c|c|c|c|c|c|}
\hline & \multirow[t]{2}{*}{ n } & \multicolumn{2}{|c|}{ Men } & \multirow[t]{2}{*}{$\mathbf{n}$} & \multicolumn{2}{|c|}{ Women } \\
\hline & & Mean \pm SD & Min-Max & & Mean \pm SD & Min-Max \\
\hline $\mathrm{CC}^{*}$ & 226 & $1411.64 \pm 118.9$ & $1137-1798$ & 140 & $1306.95 \pm 162.9$ & $991-1939$ \\
\hline F1 & 226 & $1411.63 \pm 42.4$ & $1347-1531$ & 140 & $1306.94 \pm 63.2$ & $1217-1487$ \\
\hline F2 & 226 & $1411.06 \pm 42.6$ & $1320-1534$ & 140 & $1306.87 \pm 96.6$ & $1147-1603$ \\
\hline F3 & 226 & $1411.03 \pm 32.3$ & 1339-1489 & 140 & $1306.26 \pm 101.8$ & $1116-1629$ \\
\hline F4 & 226 & $1411.57 \pm 29.6$ & $1344-1469$ & 140 & $1306.94 \pm 36.4$ & $1252-1396$ \\
\hline F5 & 226 & $1411.67 \pm 118.8$ & $1134-1797$ & 140 & $1306.98 \pm 162.9$ & $987-1934$ \\
\hline
\end{tabular}

*Males : 0.000337(L-11) (W-11) (H-11) +406.01, Females: 0.000400(L-11) (W-11) (H-11) +206.60

The relation between $\mathrm{CC}$ and age is expressed in the following regression equation:

$\mathrm{CC}=999.268+(20.46 \mathrm{x}$ Age) (for male), $563.926+(38.47 \times$ x Age) (for female). There was a strong correlation between CC and age $(\mathrm{p}<0.001, \mathrm{r}: 0.160)$ (Fig. 1).

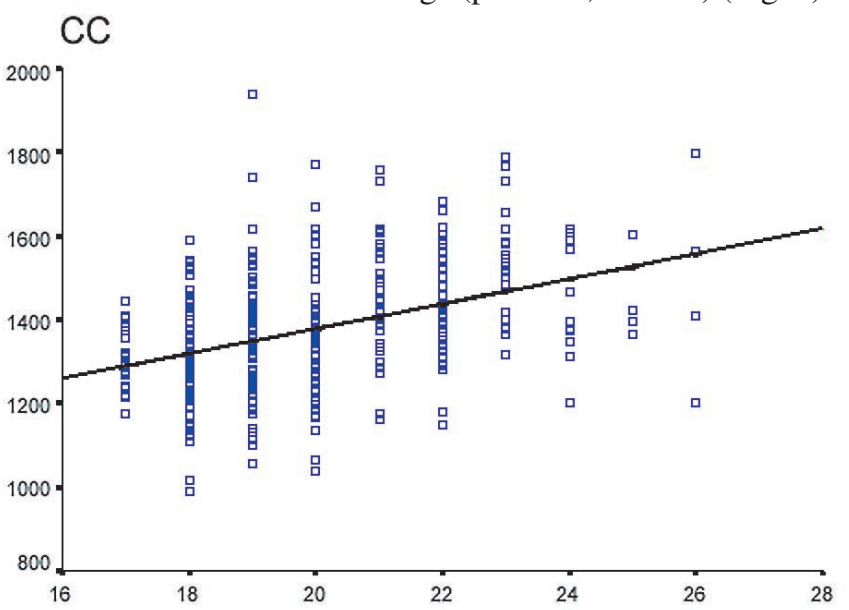

AGE

Fig. 1. Scatter plots and regression lines showing the relationship between age and $\mathrm{CC}$ in both sexes.

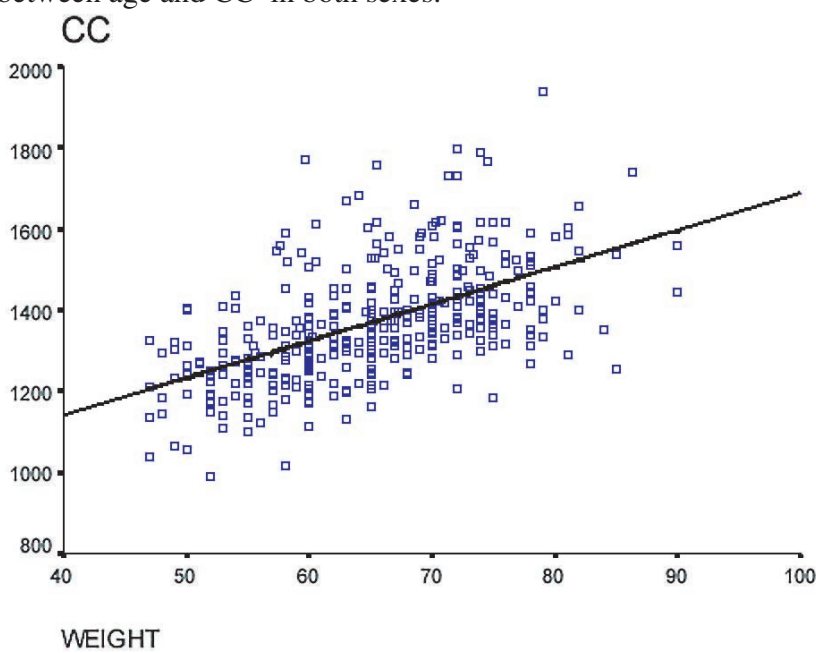

Fig. 2. Scatter plots and regression lines showing the relationship between weight and $\mathrm{CC}$ in both sexes.
The relation between $\mathrm{CC}$ and body weight is expressed in the following regression equation: $\mathrm{CC}=984.136+(6.12 \times$ Weight $)$ (for male), 477.362+(14.25 x Weight) (for female). There was a strong correlation between $\mathrm{CC}$ and body weight (p<0.001, r:0.305) (Fig. 2).

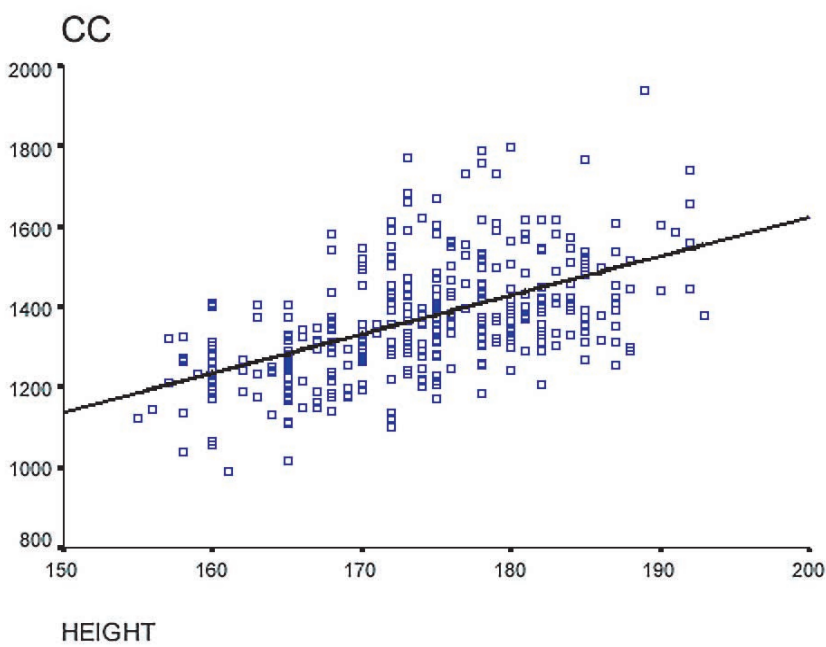

Fig. 3. Scatter plots and regression lines showing the relationship between height and $\mathrm{CC}$ in both sexes.

The relation between $\mathrm{CC}$ and body height is expressed in the following regression equation:

$\mathrm{CC}=453.439+(5.37 \mathrm{x}$ Height$)$ (for male), -1222.6+ (15.09 x Height) (for female). There was a strong correlation between CC and body height ( $\mathrm{p}<0.001, \mathrm{r}: 0.293)$ (Fig. 3).

The relation between $\mathrm{CC}$ and $\mathrm{BMI}$ is expressed in the following regression equation: $\mathrm{CC}=978.694+(19.76 \mathrm{x} \mathrm{BMI}$ ) (for male), 803.856+ (24.33 x BMI)(for female). There was a strong correlation between CC and BMI (p<0.001, r:0.111) (Fig. 4).

The relation between $\mathrm{CC}$ and $\mathrm{WxHxL}$ is expressed in the following regression equation: $\mathrm{CC}=320.457+(0.2929 \mathrm{x}$ WxHxL) (for male), 112.217+ (0.3455 x WxHxL)(for female). There was a strong correlation between $\mathrm{CC}$ and WxHxL (p<0.001, r:0.990) (Fig. 5). 


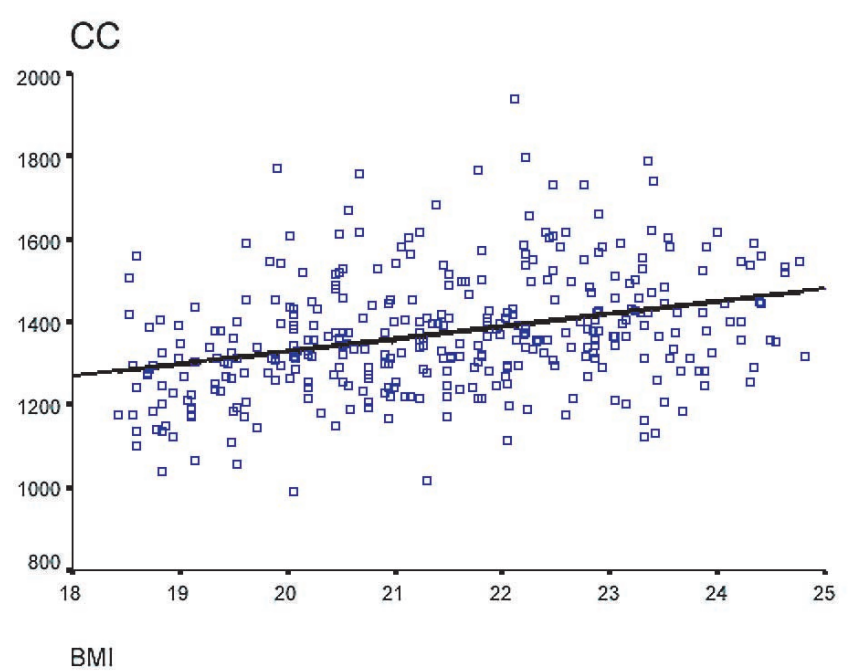

Fig. 4. Scatter plots and regression lines showing the relationship between BMI and $\mathrm{CC}$ in both sexes.

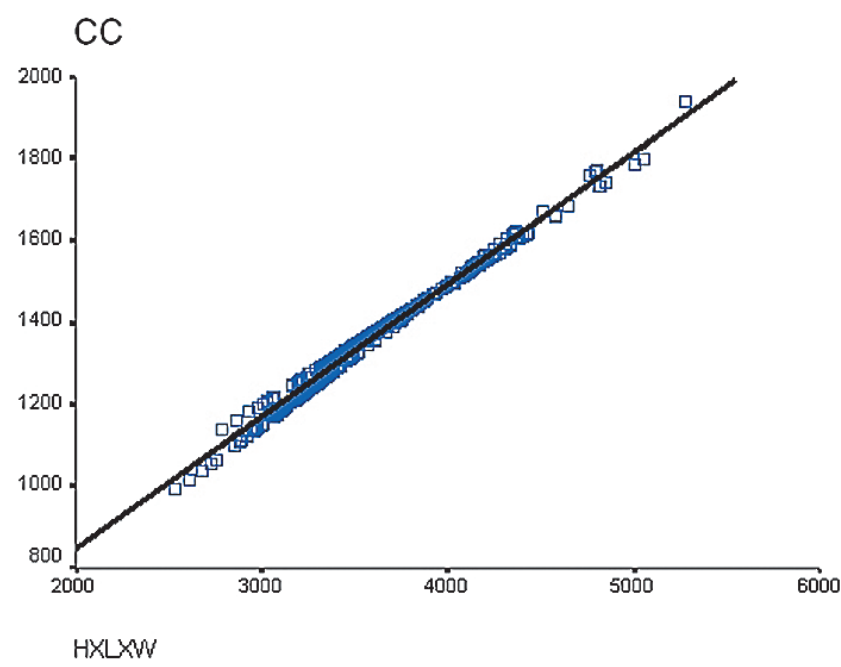

Fig. 5. Scatter plots and regression lines showing the relationship between $\mathrm{W} x \mathrm{HxL}$ and cranial capacity in both sexes.

The results of CC values were compared statistically. There was no difference between CC values and age, body weight, body height, BMI formulaes ( $\mathrm{p}>0.05$ ) (Table III).

\section{DISCUSSION}

Many of studies showed that the CC accompany increasing age from birth throughout childhood. Most growth is achieved in the first 5 years (Sgouros et al., 1999; Piatt \& Arguelles, 1991). At the age of 16-20 the CC reaches its peak size and it is thought that the $\mathrm{CC}$ does not change its size during the rest of the life (Knutson et al., 2001; Wolf et al.).
Several investigators have estimated the $\mathrm{CC}$ in the past which indirectly reflects the brain volume (Gault et al.; Mazonakis et al., 2004; Wolf et al. ). Most of these studies have been made on the dry skulls using linear dimensions, packing methods or occasionally radiological methods (MacKinnon; Dekaban; Manjunath, 2002a; Mazonakis et $a l$.$) .$

The CC of skulls belonging to different races has been determined by several authors (Manjunath, 2002a; Hwang et al.; Golalipour et al.;). Manjunath (2002a) reported the cranial volume was $1152.813 \pm 279.16 \mathrm{~cm}^{3}$ in males and $1117.82 \pm 99.09 \mathrm{~cm}^{3}$ in females. According Hwang report's, the cranial volume was $1470 \pm 107 \mathrm{~cm}^{3}$ in males and $1317 \pm 117$ $\mathrm{cm}^{3}$ in female skull. Golalipour et al. reported cranial capacity of the Turkman was $1420.60 \pm 85 \mathrm{~cm}^{3}$ in male and $1227.2 \pm 120 \mathrm{~cm}^{3}$ in females, and in native Fars group in male and female were $1369.4 \pm 142 \mathrm{~cm}^{3}$ and $1215.8 \pm 125 \mathrm{~cm}^{3}$, respectively. Also, Dekaban reported cranial volume, 1548 $\mathrm{cm}^{3}$ in males and $1425 \mathrm{~cm}^{3}$ in females. In this study, determined average cranial capacity was $1375.67 \pm 91.17 \mathrm{~cm}^{3}$ in males and $1237.32 \pm 95.12 \mathrm{~cm}^{3}$ in females. The findings of this research are higher than Indian skulls and lower than Korean, supports the observation of Golalipour et al., Turkman group.

Age-related decrease in the weight of adult brains has often been noted in cross-sectional studies. Some investigators have questioned whether such decreases are due to aging, because it is known that the stature of humans, as well as the size of the head and brain, has increased during the last century. The most likely explanation is that the head size of humans, and consequently the intracranial volume, increases with age and that such changes mask the longterm trend that affects the population as a whole (Ho et al., 1980).

Pearl (1905) found that at the young subject, the correlation for the following pairs of characters: brain weight and stature, brain weight and age, brain weight and skull length, brain weight and skull width.

An initial linear regression analysis examined the effect of age and BMI on normalized brain volume to determine whether the effect observed in elderly females could be observed in younger men and women (Gustafson et al., 2004). Ward et al. (2005) indicated that to determine whether additional variables may also predict normalized brain volume, a stepwise linear regression analysis was used to examine the effects of age, BMI and gender on normalized brain volume. Ward's results showed that age and BMI together were the best predictors of normalized brain volume. In addition, BMI affects brain volume at a relatively young 
age extends prior research on the harmful effects of obesity on the brain. Ward et al. also stated that age and BMI were each associated with decreased brain volume in 40-66 years old (54.2 \pm 6.6$)$.

Ruben et al. (1991) reported age was negatively correlated with brain volume between 18-80 years old 69 subject. Etsuro et al. (1997) reported the mean total intracranial volume for the group of normal subjects was $1472 \mathrm{~cm}^{3}$; the mean for the women was $1413 \mathrm{~cm}^{3}$, and the mean for the men was $1551 \mathrm{~cm}^{3}$. Mazonakis et al. stated that the techniques of stereology and planimetry provided a mean intracranial cavity volume $( \pm S D)$ of $1323.0 \pm 180.7$ and $1329.1 \pm 168.5 \mathrm{~cm}^{3}$, respectively. Acer et al., stated that the means of the intracranial volume was $1311+133 \mathrm{~cm}^{3}$. The means and range of values are comparable with earlier reports. We also found support for the cranial volume increases the correlations with age, and all effects sustained controlling for height, and weight.

In conclusion an increase of $\mathrm{CC}$ resulted in increase of the body height, body weight and BMI. There are satisfactory correlation between age, BMI, $\mathrm{WxHxL}$ and CC. Thus actually proved to be easy using these formulae for calculate CC.

It may be perhaps helpful in medico legal and anthropological examination to find the relations between cranial capacity and age, height, body weight, BMI which could also be applied for the dementia, brain atrophy and other neurodegenerative diseases in living subjects.

ACER, N., USANMAZ, M.; TUGAY, U. \& ERTEKI'N, T. Estimación de la capacidad craneana en estudiantes universitarios entre 17 y 26 años de edad. Int. J. Morphol., 25(1):65-70, 2007.

RESUMEN: Es natural que exista una relación entre la capacidad craneana y el tamaño del cerebro. Numerosos estudios realizados, han estimado la capacidad craneana con lo cual han determinado indirectamente el volumen del cerebro. El estudio fue realizado en 366 individuos (226 hombres y 140 mujeres), normales, entre 17-26 de edad, pertenecientes a grupos del Mugla Universidad de Mugla, Turquía. Para la estimación de la capacidad craneana se utilizaron las dimensiones lineales de la cabeza. La media y SD de la capacidad craneana en hombres y mujeres, fue de $1411,64 \pm 118,9 \mathrm{~cm}^{3}$ y $1306,95 \pm 162,9 \mathrm{~cm}^{3}$, respectivamente. Las diferencias fueron estadísticamente significativas $(\mathrm{p}<0.05)$. La investigación demostró que la capacidad craneana es mayor en los hombres que en las mujeres. También propusimos una fórmula de regresión que podría ser usada para predecir la capacidad craneana.

\section{PALABRAS CLAVE: Craneometría; Capacidad craneana; Fórmula de regresión.}

\section{REFERENCES}

Acer, N.; Sahin, B.; Ekinci, N.; Basaloglu, H. \& Ergür, H. Relation Between Intracranial Volume and the Surface Area of the Foramen Magnum. J. Craniofac. Surg., 17:326-30, 2006.

Dekaban, A. Tables of cranial and orbital measurements, cranial volume and derived indices in males and female from 7 days to 20 yrs of age. Annals of Neurology, 2:485-9, 1977.

Gault, D.; Brunelle, F.; Renier, D. \& Marchac, D. The calculation of intracranial volume using CT scans. Childs Nerv. Syst., 4:271-3, 1988.

Golalipour, M. J.; Jahanshaei, M. \& Haidari, K. Estimation of cranial capacity in 17-20 years old in South East of Caspian Sea Border (North of Iran). Int. J. Morphol., 23(4):301-4, 2005.

Gustafson, D.; Lissner, L.; Bengtsson, C.; Bjorkelund, C. \& Skoog, I. A 24- year follow-up of body mass index and cerebral atrophy. Neurology, 63:1876-81, 2004.
Haack, D. C. \& Meihoff. A method for estimation of cranial capacity from cephalometric Roentgnograms. Am. J. Phys. Anthropol., 34:447-52, 1971.

Ho, K. C.; Roessmann, U.; Straumfjord, J. V. \& Monroe, G. Analysis of brain weight. I. Adult brain weight in relation to sex, race, and age. Arch. Pathol. Lab. Med., 104:6359, 1980 .

Hwang, Y.; Lee, K. H.; Choi, B.; Lee, K. S. \& Lee, H. Y. Study on the Korean adult cranical capacity. J. Korean Sci., 10:239-42, 1995.

Knutson, B.; Momenan, R. \& Rawlings, R. R. Negative association of neuroticism with brain volume ratio in healthy humans. Biol. Psychiatry, 50:685-90, 2001.

MacKinnon, I. L. The relation of the capacity of the human skull to its roentgenological length American Journal of Roentgenology, Am. J. Roentgenol. Radium. Ther. Nucl. Med., 14:1026-9, 1955. 
Manjunath, K. Y. Estimation of Cranial Volume in Dissecting Room Cadavers. J. Anat. Soc. India., 51:168-72, 2002a.

Manjunath, K. Y. Estimation of Cranial Volume-an Overview of Methodologies. J. Anat. Soc. India, 51:85-91, 2002b.

Mazonakis, M.; Karampekios, S.; Damilakis, J.; Voloudaki, A. \& Gourtsoyiannis, N. Stereological estimation of total intracranial volume on CT images. Eur. Radiol., 14:1285-90, 2004.

Pearl, R. Biometrical studies on man. I. Variation and correlation in brain-weight. Biometrika, 4:13-104, 1905.

Piatt, J. H. Jr. \& Arguelles, J. H. Reduction cranioplasty for craniocerebral disproportion in infancy: indications and technique. Pediatr. Neurosurg., 16:265-70, 1991.

Report of a WHO consultation. Obesity: preventing and managing the global epidemic. World Health Organ Tech. Rep. Ser., 894:i-xii, 1-253, 2000.

Sgouros, S.; Goldin, J. H. \& Hockley, A.D. Intracranial volume change in childhood. J. Neurosurg., 91:610-6, 1999.

Ward, M. A.; Carlsson, M. C.; Mehul, A.; Trivedi, L.; Sager, M. A. \& Johnson, S. C. The effect of body mass index on global brain volume in middle-aged adults: a cross sectional study. BMC Neurology, 5:23, 2005.

Williams, P. L.; Bannister, L. H. \& Berry, M. M. Gray's Anatomy. Soames, R. W. Edn. 38 ${ }^{\text {th }}$. Churchill Livingstone, London. pp. 612-5, 1995.

Wolf, H.; Kruggel, F.; Hensel, A.; Wahlund, L. O.; Arendt, T. \& Gertz, H. J.The relationship between head size and intracranial volume in elderly subjects. Brain Res., 23 (973):74-80, 2003.
Correspondence to:

Dr. Niyazi Acer, PhD., Assist. Prof. Mugla Universitesi

Mugla Saglık Yuksekokulu, Mugla TURKEY

Fax No: +90 2522124755

Tel No: +902522120426

Email: nacer@mu.edu.tr

Received: 18-10-2006

Accepted: 20-01-2007 